\title{
Production of CO-rich Hydrogen Gas from Methane Dry Reforming over $\mathrm{Co} / \mathrm{CeO}_{2}$ Catalyst
}

\author{
Bamidele V. Ayodele, Maksudur R. Khan, Chin Kui Cheng* \\ ${ }^{1}$ Faculty of Chemical \& Natural Resources Engineering, Universiti Malaysia Pahang, \\ Lebuhraya Tun Razak, 26300 Gambang Kuantan, Pahang, Malaysia
}

Received: 21st January 2016; Revised: 23rd February 2016; Accepted: 23 ${ }^{\text {rd }}$ February 2016

\begin{abstract}
Production of CO-rich hydrogen gas from methane dry reforming was investigated over $\mathrm{CeO}_{2-}$ supported Co catalyst. The catalyst was synthesized by wet impregnation and subsequently characterized by field emission scanning electron microscope (FESEM), energy-dispersive X-ray spectroscopy (EDX), liquid $\mathrm{N}_{2}$ adsorption-desorption, X-ray diffraction (XRD), Fourier transform infrared spectroscopy (FTIR) and thermogravimetric analysis (TGA) for the structure, surface and thermal properties. The catalytic activity test of the $\mathrm{Co} / \mathrm{CeO}_{2}$ was investigated between $923-1023 \mathrm{~K}$ under reaction conditions in a stainless steel fixed bed reactor. The composition of the products $\left(\mathrm{CO}\right.$ and $\left.\mathrm{H}_{2}\right)$ from the methane dry reforming reaction was measured by gas chromatography (GC) coupled with thermal conductivity detector (TCD). The effects of feed ratios and reaction temperatures were investigated on the catalytic activity toward product selectivity, yield, and syngas ratio. Significantly, the selectivity and yield of both $\mathrm{H}_{2}$ and $\mathrm{CO}$ increases with feed ratio and temperature. However, the catalyst shows higher activity towards $\mathrm{CO}$ selectivity. The highest $\mathrm{H}_{2}$ and $\mathrm{CO}$ selectivity of $19.56 \%$ and $20.95 \%$ respectively were obtained at $1023 \mathrm{~K}$ while the highest yield of $41.98 \%$ and $38.05 \%$ were recorded for $\mathrm{H}_{2}$ and $\mathrm{CO}$ under the same condition. Copyright $@ 2016$ BCREC GROUP. All rights reserved
\end{abstract}

Abstract

Keywords: Methane dry reforming; hydrogen; syngas; $\mathrm{Co} / \mathrm{CeO}_{2}$ Catalyst; CO-rich Hydrogen Gas

How to Cite: Ayodele, B.V., Khan, M.R., Cheng, C. K. (2016). Production of CO-rich Hydrogen Gas from Methane Dry Reforming over $\mathrm{Co} / \mathrm{CeO}_{2}$ Catalyst. Bulletin of Chemical Reaction Engineering \& Catalysis, 11 (2): 210-219 (doi:10.9767/bcrec.11.2.552.210-219)

Permalink/DOI: http://dx.doi.org/10.9767/bcrec.11.2.552.210-219

\section{Introduction}

In the past three decades, there has been an increasing trend in the global hydrogen production [1] due to its wide applications as an energy carrier [2]. Hydrogen gas is widely used

* Corresponding Author.

E-mail: chinkui@ump.edu.my (C.K. Cheng), bamidele.ayodele@uniben.edu (B.V. Ayodele) Tel: +60-9-5492896, Fax: +60-9-5492889 for different industrial processes such as fertilizer and methanol production, crude oil refining, metal refining, food processing and electronics manufacturing [3-4]. Recently, attention of researchers have shifted to the use of hydrogen as fuel source due to its high calorific value [5-6]. This has resulted into breakthrough in the application of hydrogen fuel cells as source of energy for propelling spacecraft, powering remote weather stations and submarines as well as electric vehicles [7-8]. 
The mixture of $\mathrm{H}_{2}$ and $\mathrm{CO}$ otherwise known as synthesis (syngas) can also be employed as chemical intermediate for the production of synthetic fuel either through Fischer-Tropsch synthesis or Mobil Methanol-To-Gasoline process [9-10].

Hydrogen gas can be produced using different technologies such as natural gas reforming [11], gasification (biomass or coal) [12] and through biological process [13]. Coal gasification is one of the early technologies employed in the production of $\mathrm{H}_{2}$ and it is being used by SASOL for commercial production of hydrogen [14]. However, the process has raised a lot of environmental concerns due to $\mathrm{CO}_{2}$ and carcinogen emissions that often come with the process [15]. Presently, about $50 \%$ of the world consumption of hydrogen is commercially produced from natural gas reforming otherwise known as steam reforming of methane (Equation (1)) [16]. Besides steam methane reforming, hydrogen can also be produced from partial oxidation of methane [17] (Equation (2)) which involves the partial combustion of methane in air. These two processes (steam methane reforming and partial oxidation) produce syngas which can further be converted to higher content of hydrogen through water gas shift reaction represented in Equation (3).

$$
\mathrm{CH}_{4}+\mathrm{H}_{2} \mathrm{O} \leftrightarrow \mathrm{CO}+3 \mathrm{H}_{2}
$$

$$
\Delta H_{r}^{\circ}=206 \mathrm{kJmol}^{-1}
$$

$$
\mathrm{CH}_{4}+\frac{3}{2} \mathrm{O}_{2} \rightarrow \mathrm{CO}+2 \mathrm{H}_{2}
$$

$$
\Delta H_{r}^{\circ}=165 \mathrm{kJmol}^{-1}
$$

$$
\mathrm{CO}+\mathrm{H}_{2} \mathrm{O} \leftrightarrow \mathrm{CO}_{2}+\mathrm{H}_{2}
$$

$$
\Delta H_{r}^{\circ}=-41.2 \mathrm{kJmol}^{-1}
$$

Although, methane steam reforming and coal gasification are well established technologies for $\mathrm{H}_{2}$ production, nevertheless, the process does not mitigate $\mathrm{CO}_{2}$ emission into the atmosphere [18]. Moreover, catalyst deactivation from sulfur poisoning, sintering and carbon deposition are also major constraints associated with $\mathrm{H}_{2}$ production using methane steam reforming [19].

A more environmental friendly way of producing $\mathrm{H}_{2}$ is through the reaction of $\mathrm{CO}_{2}$ with natural gas (methane) otherwise known as methane dry reforming (Equation (4)) [20]. Methane dry reforming has the advantage of utilizing the two principal components of greenhouse gases for $\mathrm{H}_{2}$ or syngas production compared to gasification and steam reforming process [21]. Besides, the process produces $\mathrm{H}_{2} / \mathrm{CO}$ ratio $<2$, suitable for the production of synthetic fuel via Fischer-Tropsch synthesis [22].

$$
\begin{aligned}
\mathrm{CH}_{4}+\mathrm{CO} \leftrightarrow 2 \mathrm{CO}+2 \mathrm{H}_{2} \\
\Delta H_{r}^{\circ}=247 \mathrm{kJmol}^{-1}
\end{aligned}
$$

Nonetheless, the process is also prone to catalysts deactivation from sintering and carbon deposition due to the high temperature requirement of the reaction [23]. In an attempt to design and develop more stable catalysts, metal catalysts, such as: $\mathrm{Ru}, \mathrm{Pt}, \mathrm{Co}, \mathrm{Pd}$, Ir, dispersed on different supports $\left(\mathrm{Al}_{2} \mathrm{O}_{3}, \mathrm{ZrO}_{2}, \mathrm{SiO}_{2}, \mathrm{MgO}\right.$ and $\mathrm{CeO}_{2}$ ) have been investigated for methane dry reforming [24]. However, very few literatures have reported hydrogen production over $\mathrm{Co} / \mathrm{CeO}_{2}$ catalyst.

Luisetto et al. [25] investigated the catalytic properties of $\mathrm{Co}-\mathrm{Ni}$ bimetallic catalyst supported on $\mathrm{CeO}_{2}$ in methane dry reforming and compared the catalytic activity with $\mathrm{CeO}_{2}$ supported $\mathrm{Co}$ and $\mathrm{Ni}$ monometallic catalysts. The findings show that the $\mathrm{Co}-\mathrm{Ni}$ bimetallic catalyst displayed higher activity compared to the supported $\mathrm{Co}$ and $\mathrm{Ni}$ monometallic catalysts. Recently, Abasaeed et al. [26] investigated $\mathrm{H}_{2}$ production from methane dry reforming over nano-oxides $\left(\mathrm{CeO}_{2}\right.$ and $\left.\mathrm{ZrO}_{2}\right)$ supported $\mathrm{Co}$ catalysts. The effects of calcinations temperature ranged from $773-1173 \mathrm{~K}$ on the catalysts activities were evaluated. The results of the study show that the catalysts calcined at 773 and $873 \mathrm{~K}$ exhibited higher $\mathrm{H}_{2}$ yield compared to those calcined at higher temperature.

In the present study, production of CO-rich $\mathrm{H}_{2}$ from methane dry reforming over $\mathrm{CeO}_{2}$ supported $\mathrm{Co}$ catalyst is reported. The $\mathrm{CeO}_{2}$ support was synthesized by thermal decomposition of Cerium(II) nitrate hexahydrate. The main objective of this study is to investigate the catalytic activity of $\mathrm{CeO}_{2}$ supported Co catalyst in methane dry reforming for $\mathrm{CO}$-rich $\mathrm{H}_{2}$ production.

\section{Materials and Methods}

\subsection{Catalyst synthesis}

First, the $\mathrm{CeO}_{2}$ support was prepared by 
thermal decomposition of ceriun(II) nitrate hexanitrate (99.99\% purity, Sigma-Aldrich) in a furnace at $773 \mathrm{~K}$ for 2 hours [27]. The $20 \mathrm{wt} \%$ $\mathrm{Co} / \mathrm{CeO}_{2}$ catalyst was prepared by impregnating the $\mathrm{CeO}_{2}$ support with aqueous solution of cobalt(III) nitrate hexanitrate (99.99\% purity, Sigma-Aldrich) to produce 20 wt\% Co loading. The mixture was continuously stirred for 3 hours, dried in the oven for $24 \mathrm{~h}$ at $393 \mathrm{~K}$ and then calcined at $873 \mathrm{~K}$ for $5 \mathrm{~h}$.

\subsection{Catalyst characterization}

Temperature programmed calcination of the fresh catalysts was performed by Thermogravimetric analyzer (TGA) (TA instrument) in the temperature range from 298-1173 $\mathrm{K}$ under compressed air in order to determine the thermal stability of the catalyst. The crystallinity of the catalysts was measured by X-ray diffraction analysis (XRD). The XRD was carried out using a RIGAKU miniflex II X-ray diffractometer with $\mathrm{Cu} \mathrm{K} \alpha \mathrm{X}$-ray source at wavelength $(\lambda)$ of $0.154 \mathrm{~nm}$ radiation.

The catalysts surface morphology and the elemental composition were analyzed by field emission scanning electron microscopy (FESEM) coupled with energy dispersive X-ray (EDX) spectroscopy. Information on the textural properties of the catalyst was obtained from $\mathrm{N}_{2}$ adsorption-desorption isotherms data by Thermo Scientific Surfer analyzer. The sample was degassed at $523 \mathrm{~K}$ for $4 \mathrm{~h}$ prior to the

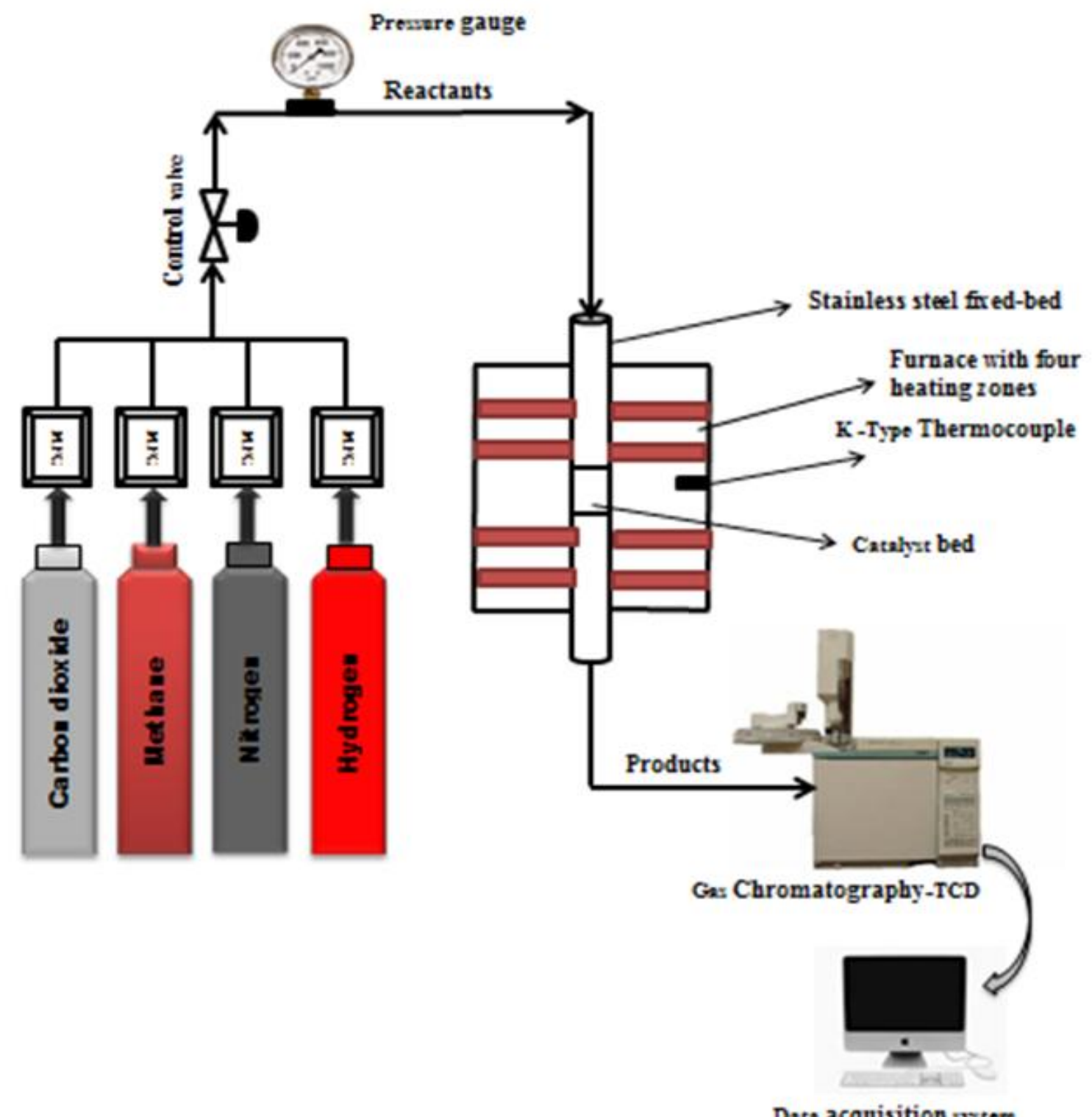

Figure 1. Schematic representation of experimental set up for CO-rich $\mathrm{H}_{2}$ production from methane dry reforming over $\mathrm{Co} / \mathrm{CeO}_{2}$ catalyst 
measurement of the $\mathrm{N}_{2}$ adsorption-desorption isotherm at $77 \mathrm{~K}$. The pore size distribution and the average pore diameter were determined from desorption section of the isotherm by Barret-Joyner-Halenda (BJH) method. The nature of the chemical bonding of the catalyst was determined by Fourier transform infra-red spectroscopy (FTIR) (Thermo Scientific, Nicolet iS-50). The spectra were obtained using Thermo-Scientific IR spectrometer at room temperature with accumulation of 16 scans at a resolution of $4 \mathrm{~cm}^{-1}$.

\subsection{Catalytic activity for Co-rich $\mathrm{H}_{2}$ pro- duction}

The experimental set up for $\mathrm{CO}$-rich $\mathrm{H}_{2}$ production over $\mathrm{Co} / \mathrm{CeO}_{2}$ catalyst is depicted in Figure 1. The methane dry reforming was performed at atmospheric pressure in tubular stainless fixed bed reactor containing $200 \mathrm{mg}$ of the catalysts supported with quartz wool. The tubular fixed bed reactor (internal diameter: 10 $\mathrm{mm}$; Height $35 \mathrm{~cm}$ ) was placed vertically in a furnace with four heating zones equipped with $\mathrm{K}$-type thermocouple to measure the temperature of the catalyst bed. The catalyst was reduced in-situ under the flow of $60 \mathrm{~mL} / \mathrm{min}$ of $\mathrm{H}_{2} / \mathrm{N}_{2}$ (ratio $1: 5$ ) at $873 \mathrm{~K}$ for $1 \mathrm{~h}$. The reactant gases $\left(\mathrm{CO}_{2}\right.$ and $\left.\mathrm{CH}_{4}\right)$ were fed into the fixed bed reactor at feed ratios $\left(\mathrm{CO}_{2}: \mathrm{CH}_{4}\right)$ ranged from 0.1 to 1.0. The methane dry reforming was performed at reaction temperatures 923-1023 K. The products and reactants were analyzed by gas chromatography instrument (GC-Agilent $6890 \mathrm{~N}$ series) equipped with thermal conductivity detector (TCD). The catalyst performances were evaluated by yields and selectivity defined in Equations (5-8) [4-5].

$$
\begin{aligned}
& \mathrm{H}_{2} \text { Yield }(\%)=\frac{\text { moles of } \mathrm{H}_{2} \text { produced }}{2 \text { moles of } \mathrm{CH}_{4} \text { feed }} \times 100 \% \\
& \text { CO yield }(\%)=\frac{\text { moles of } \mathrm{CO} \text { produced }}{\left(\text { moles of } \mathrm{CH} 4+\text { moles of } \mathrm{CO}_{2}\right)_{\text {feed }}} \times 100 \%
\end{aligned}
$$

Selectivit y of $H_{2}(\%)=$

$$
\frac{\text { mole of } \mathrm{H}_{2}}{\left(\text { moles of } \mathrm{H}_{2}+\text { total moles } \mathrm{C}-\text { containing products }\right)_{\text {outlet }}} \times 100 \%
$$

$$
\begin{aligned}
& \text { Selectivity of } \mathrm{CO}(\%)= \\
& \frac{\text { mole of } \mathrm{CO}}{(\text { moles of } \mathrm{CO}+\text { total moles } C-\text { containing products })_{\text {outlet }}} \times 100 \%
\end{aligned}
$$

\section{Results and Discussion}

\subsection{Catalysts characterization}

The thermal behavior of the catalyst under temperature programmed calcination from 298 to $1173 \mathrm{~K}$ is represented by the thermogravimetry (TG) and the differential thermogravimetry (DTG) curves in Figure 2. Significantly, there are four different weight loses represented by peaks I-IV on the DTG curve. The weight changes could be attributed to sequential loss of physical and hydrated water represented by peak I-III and then decomposition of $\mathrm{Co}\left(\mathrm{NO}_{3}\right)_{2}$ (Equation (9)) [30].

It is noteworthy that the XRD pattern of the as-synthesized $\mathrm{Co} / \mathrm{CeO}_{2}$ catalyst shows different peaks with varying intensity (cf. Figure 3 ). The XRD pattern show the existence of $\mathrm{CeO}_{2}$ with a distinct fluorite-type oxide structure [31]. The diffraction peaks of $28.8^{\circ}, 31.5^{\circ}, 33.3^{\circ}, 37.1^{\circ}$, $45.1^{\circ}, 47.7^{\circ}, 56.7^{\circ}, 59.6^{\circ}, 65.5^{\circ}, 69.8^{\circ}$ and $77.1^{\circ}$ can be ascribed to (111), (220), (200), (311), (400), (220), (311), (222), (440), (400), and (331) of the face-centered cubic (fcc) structure, respectively. Moreover, weak diffraction peak at $2 \theta$ of $31.5^{\circ}, 45.1^{\circ}, 59.6^{\circ}, 65.5^{\circ}, 69.8^{\circ}$ and $77.1^{\circ}$ can be ascribed to cubic $\mathrm{Co}_{3} \mathrm{O}_{4}$ crystallites in an unreduced state [32]. The diffraction peaks of $\mathrm{CoO}$ or Co could not be detected from the XRD pattern.

The BET measurement of the specific surface area of the catalyst from $\mathrm{N}_{2}$ adsorption-

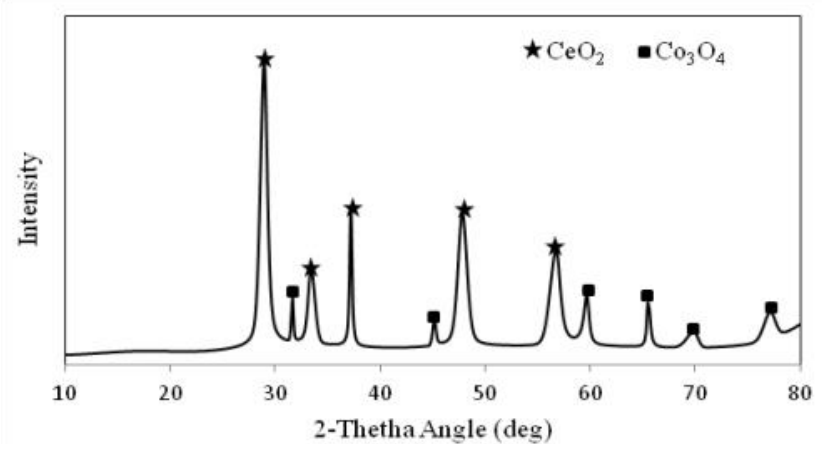

Figure 3. X-ray diffraction patterns of the fresh $\mathrm{Co} / \mathrm{CeO}_{2}$ catalyst

$$
\begin{aligned}
& \mathrm{Co}\left(\mathrm{NO}_{3}\right)_{2} \cdot 6 \mathrm{H}_{2} \mathrm{O} \stackrel{-2 \mathrm{H}_{2} \mathrm{O}}{\mathrm{I}} \mathrm{Co}\left(\mathrm{NO}_{3}\right)_{2} \cdot 4 \mathrm{H}_{2} \mathrm{O} \stackrel{-2 \mathrm{H}_{2} \mathrm{O}}{\mathrm{II}} \mathrm{Co}\left(\mathrm{NO}_{3}\right)_{2} \cdot 2 \mathrm{H}_{2} \mathrm{O} \stackrel{-2 \mathrm{H}_{2} \mathrm{O}}{\mathrm{III}} \mathrm{Co}\left(\mathrm{NO}_{3}\right)_{2} \\
& \mathrm{Co}\left(\mathrm{NO}_{3}\right)_{2} \underset{\mathrm{IV}}{\longrightarrow} \mathrm{Co}_{3} \mathrm{O}_{4}+\mathrm{N}_{2} \mathrm{O}_{5}
\end{aligned}
$$

Figure 2. Temperature programmed calcination of the fresh $\mathrm{Co} / \mathrm{CeO}_{2}$ catalyst 
desorption isotherms is shown in Figure 4. The $\mathrm{Co} / \mathrm{CeO}_{2}$ catalysts exhibited type-IV isotherm behavior signifying the presence of mesopores in the catalyst sample. The specific surface area of the catalysts was calculated to be 39.89 $\mathrm{cm}^{2} / \mathrm{g}$ which is consistent with [26]. The catalysts average pore diameter and the pore volume of $1.157 \mathrm{~nm}$ and $0.014 \mathrm{~cm}^{3} / \mathrm{g}$ respectively was estimated from the adsorption data using the BJH method.

The FTIR spectra for the $\mathrm{Co} / \mathrm{CeO}_{2}$ catalyst are depicted in Figure 5. Prior to the analysis of the sample, background spectra were collected and subsequently subtracted from the test spectra. This is to ensure that there is no interference with the spectra of the catalysts sample. The bands at $3277,1489,658$, and 608 $\mathrm{cm}^{-1}$ correspond to $\mathrm{OH}, \mathrm{CO}_{3}{ }^{2-}$ and metal oxide (M-O), respectively. The tiny bands before 608 $\mathrm{cm}^{-1}$ could be attributed to metal oxide (M-O) bonds $(\mathrm{Ce}-\mathrm{O}$ and $\mathrm{Co}-\mathrm{O})$. The presence of $\mathrm{OH}$ and $\mathrm{CO}_{3}{ }^{2-}$ could be assigned to water moisture and dissolved atmospheric carbon dioxide.

The FESEM micrographs and EDX dot mapping of the $\mathrm{Co} / \mathrm{CeO}_{2}$ catalyst are depicted in Figure 6 . The topographical and elemental information at magnifications 20000x and $80000 \times$ of the $\mathrm{Co} / \mathrm{CeO}_{2}$ sample shows that the catalyst particles agglomerated with irregular shapes in large ensembles and have comparatively rough surfaces. The EDX analysis (cf. Figure 6 (c)) shows that the elemental compositions of the catalyst are mainly made up of $\mathrm{Co}$, $\mathrm{Ce}$ and $\mathrm{O}$ in the right proportions stipulated during the catalyst preparation. The $20 \mathrm{wt} \% \mathrm{Co}$ obtained from the EDX confirms the efficacy of employing wet-impregnation method for the catalyst preparation.

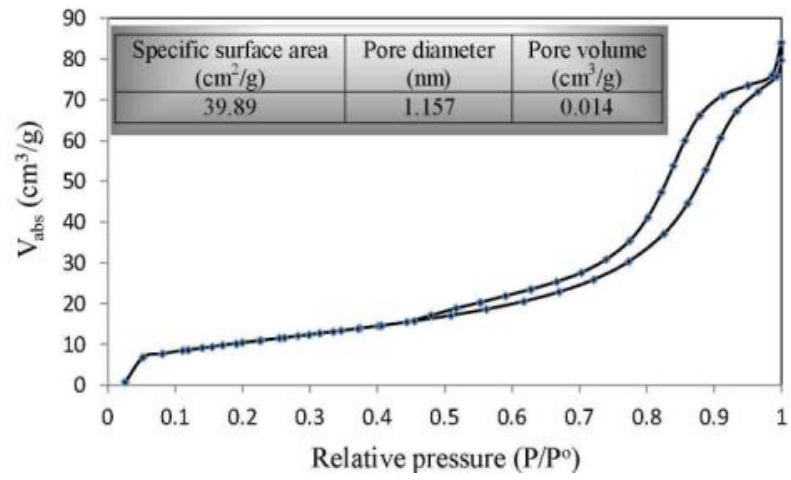

Figure 4. BET surface area determination from $\mathrm{N}_{2}$-physisorption isotherm

\subsection{Catalyst activity}

The effects of feed ratios and reaction temperature on the products $\left(\mathrm{H}_{2}\right.$ and $\left.\mathrm{CO}\right)$ selectivity are depicted in Figures 7 (a) and (b) respectively. Temperature ranged from 923 to $1023 \mathrm{~K}$ was investigated for the methane dry reforming over $\mathrm{Co} / \mathrm{CeO}_{2}$ catalyst. Significantly, the catalyst selectivity for $\mathrm{H}_{2}$ production increases with feed ratio and temperatures. This trend is consistent with the findings of Xenophon [33] who investigated $\mathrm{H}_{2}$ production from methane dry reforming over $\mathrm{Ni} / \mathrm{La}_{2} \mathrm{O}_{3}$ catalyst. The $\mathrm{Co} / \mathrm{CeO}_{2}$ catalyst recorded highest $\mathrm{H}_{2}$ selectivity of $19.56 \%$ at unity feed ratio and $1023 \mathrm{~K}$. Thermodynamically, $\mathrm{H}_{2}$ selectivity is favoured between temperatures ranged 923 to $1023 \mathrm{~K}$. The increase selectivity of the catalyst towards $\mathrm{H}_{2}$ selectivity is perhaps due to the fact that the Co active site enhances the dissociation of adsorbed $\mathrm{CH}_{4}$. The selectivity of the $\mathrm{Co} / \mathrm{CeO}_{2}$ catalyst towards $\mathrm{CO}$ production is slightly higher compared to that of $\mathrm{H}_{2}$ (Figure $7(\mathrm{~b})$ ). The CO selectivity increases with feed ratio and temperature. The highest CO selectivity of $20.95 \%$ at unity feed ratio and temperature of $1023 \mathrm{~K}$ was observed for the $\mathrm{Co} / \mathrm{CeO}{ }_{2}$ catalyst. This trend could be as a result of increase in adsorption of $\mathrm{CO}_{2}$ on the $\mathrm{CeO}_{2}$ site which gives corresponding CO. Shi et al. [34] reported similar trend in their study on methane dry reforming over $\mathrm{Ni} / \mathrm{Mo}_{2} \mathrm{C}$ catalyst. The authors' findings show that $\mathrm{CO}_{2}$ activation took place on $\mathrm{Mo}_{2} \mathrm{C}$ support site producing $\mathrm{CO}$ and $\mathrm{O}$ radical.

Hydrogen and $\mathrm{CO}$ are desired products of methane dry reforming; hence the catalytic performance in the production process could be evaluated as a function of the product yields. The effects of feed ratios and reaction temperature on $\mathrm{H}_{2}$ and $\mathrm{CO}$ yield are depicted in Figure

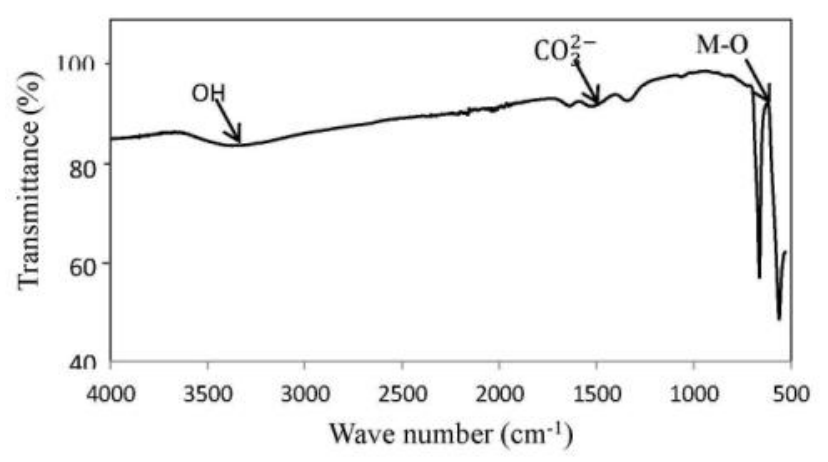

Figure 5. FTIR spectra of the fresh $\mathrm{Co} / \mathrm{CeO}_{2}$ catalyst 
8. Significantly, the CO yield increases with feed ratio and temperature (Figure 8(a)). The highest $\mathrm{CO}$ yield of $38.05 \%$ was obtained at 0.9 feed ratios and $1023 \mathrm{~K}$. It is noteworthy that $\mathrm{H}_{2}$ yield also increases with feed ratio and temperature. The $\mathrm{CeO}_{2}$ supported Co catalyst however has a higher activity toward $\mathrm{H}_{2}$ with yield of $41.98 \%$ for at unity feed ratio and $1023 \mathrm{~K}$ compared to CO. This trend is in agreement with the work of [35] in their studies on methane dry reforming over $\mathrm{MgO}$ promoted $\mathrm{Ni}-$ $\mathrm{Co} / \mathrm{Al}_{2} \mathrm{O}_{3}-\mathrm{ZrO}_{2}$ nanocatalyst. However, their findings show a higher yield of CO compared to $\mathrm{H}_{2}$. This variance could be as result of catalytic performance under different conditions.
The production of synthetic fuels via Fischer-Tropsch process requires syngas ratio $>2$. Methane dry reforming as an important method for syngas production has the advantages of producing syngas ratio close to unity [22]. The effects of feed ratios and temperature on the syngas yield $\left(\mathrm{H}_{2}+\mathrm{CO}\right)$ and syngas ratio $\left(\mathrm{H}_{2} / \mathrm{CO}\right)$ are depicted in Figure 9. The syngas yield and ratios increase with increase in feed ratio and temperature. The highest syngas yield and ratio of $78.54 \%$ and 1.28 were obtained at unity feed ratio and $1023 \mathrm{~K}$. The production of syngas ratio close to unity is favoured at feed ratio equals 0.8 and temperature of $1023 \mathrm{~K}$. The effect of reverse water gas
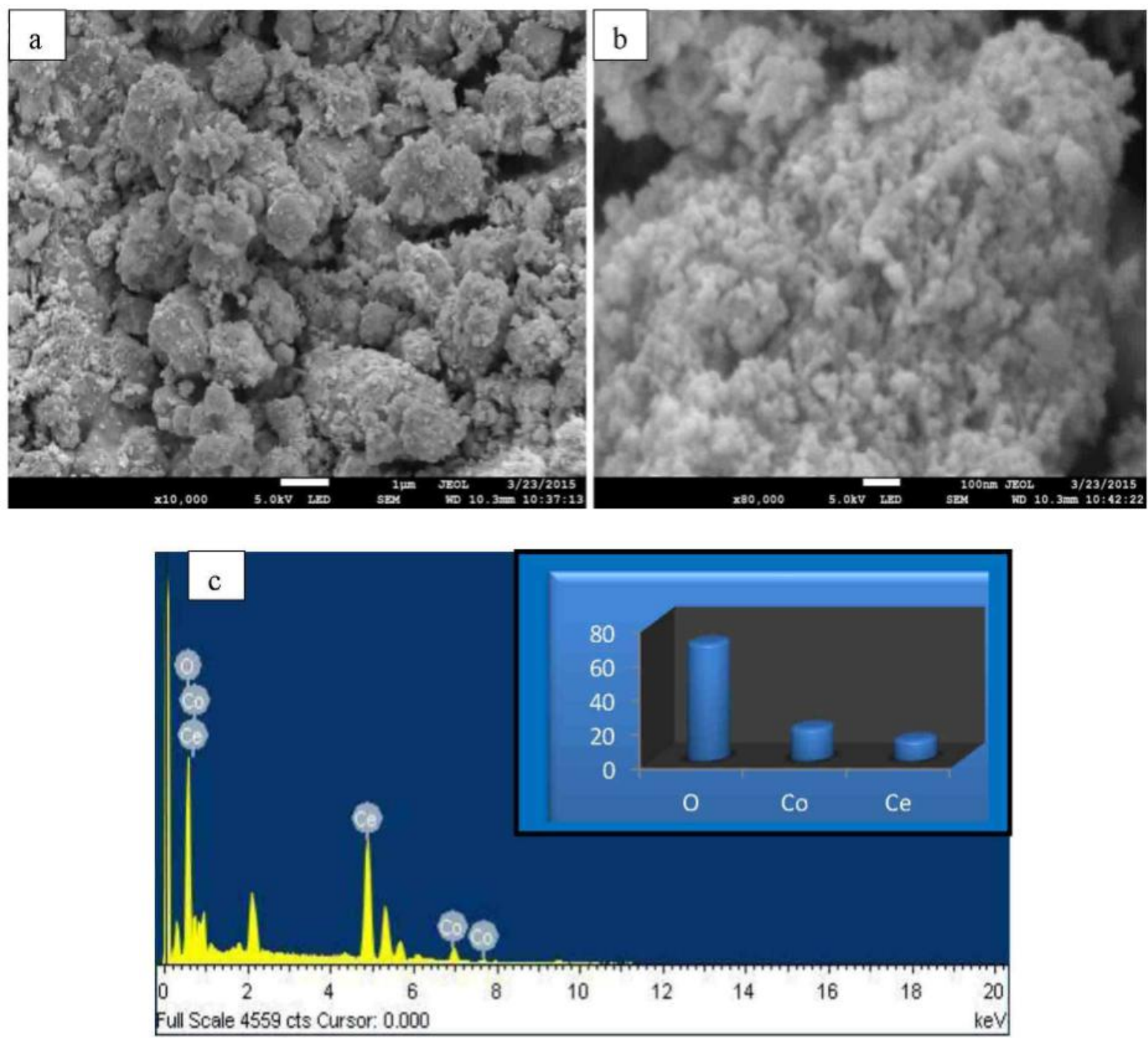

Figure 6. FESEM micrographs and EDX spectrum of the $\mathrm{Co} / \mathrm{CeO}_{2}$ catalyst (a) $\times 10000$, (b) $\times 80000$, (c) EDX image 


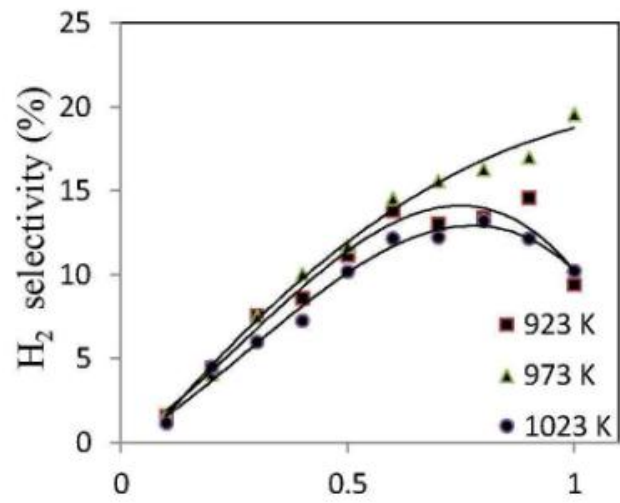

(a) $\quad \mathrm{CH}_{4}: \mathrm{CO}_{2}$ ratio

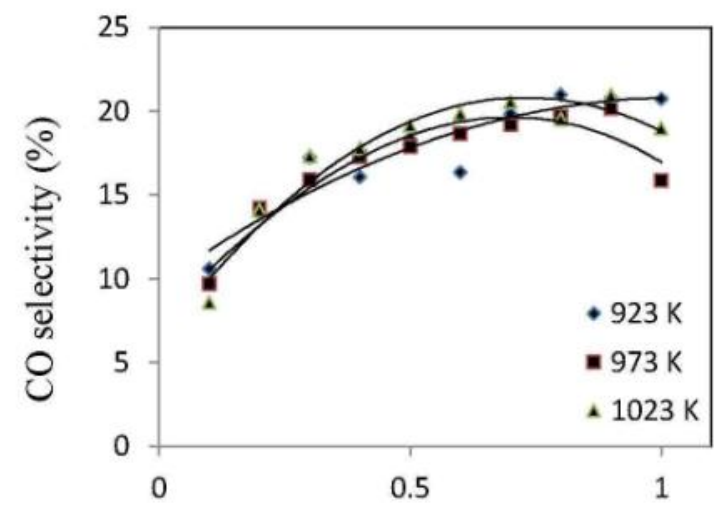

(b)

$\mathrm{CH}_{4}: \mathrm{CO}_{2}$ ratio

Figure 7. Effect of feed ratios and reaction temperature on product selectivity (a) $\mathrm{H}_{2}$, (b) CO
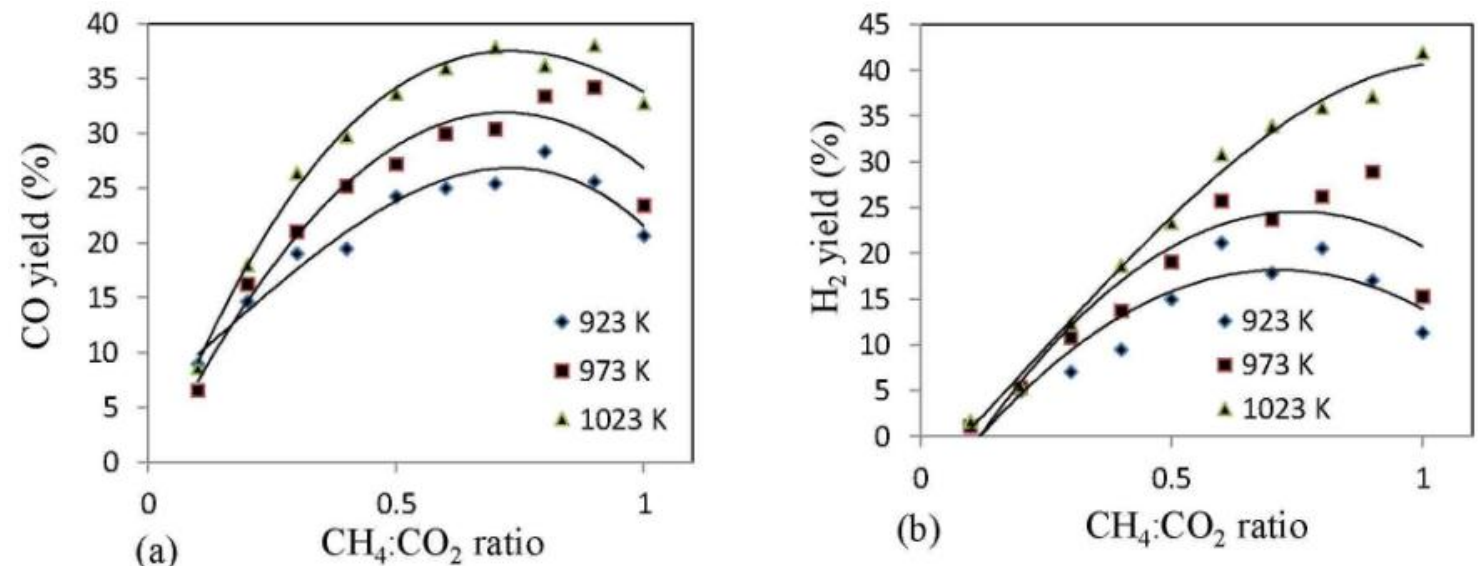

Figure 8. Effects of feed ratios and reaction temperature on product yield (a) $\mathrm{H}_{2}$, (b) $\mathrm{CO}$

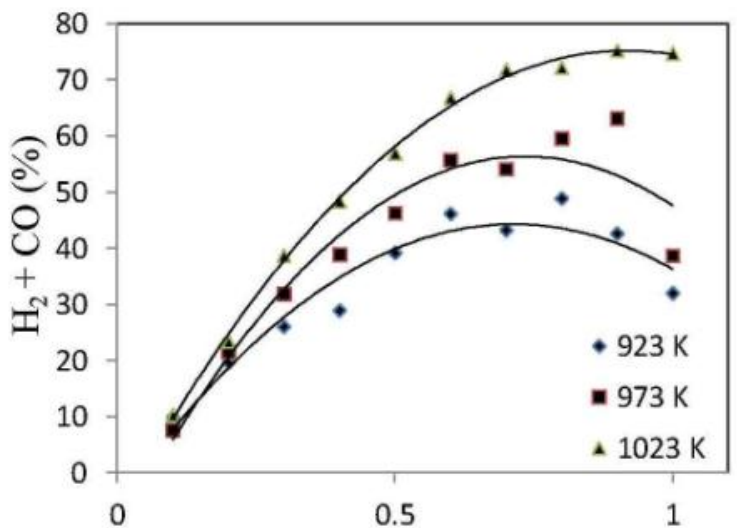

(a)

$\mathrm{CH}_{4}: \mathrm{CO}_{2}$ ratio

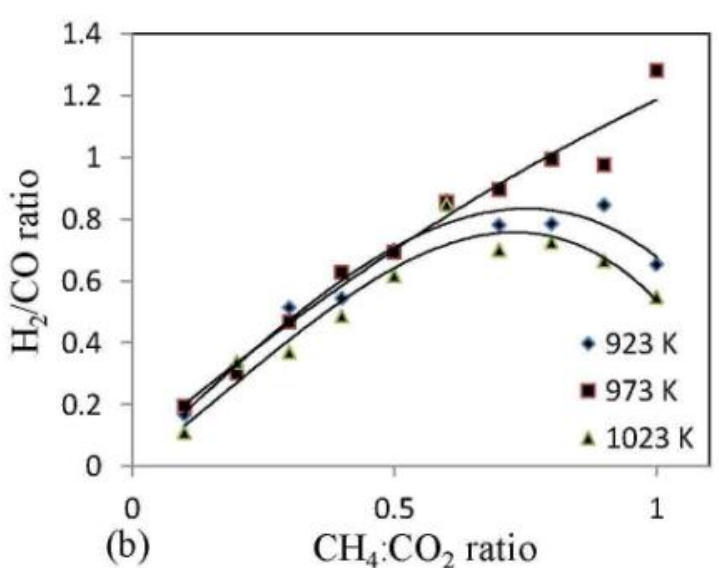

(b) $\quad \mathrm{CH}_{4}: \mathrm{CO}_{2}$ ratio

Figure 9. Effect of feed ratios and reaction temperature on (a) Syngas yield, (b) Syngas ratio 
reaction is noticeable with increase in the feed ratio, hence leads to the reduction in $\mathrm{CO}$ yield [36]. Consequentially, the syngas ratio tends to increase above unity. Findings by SerranoLotina and Daza [37] shows that production of syngas ratio close to unity is favoured at feed ratio between 0.6 and 0.9 . This trend is also corroborated by the work of [38] and [39] who obtained syngas ratio close to unity at feed ratio of 1 .

\section{Conclusions}

In this work, CO-rich hydrogen production via methane dry reforming over $\mathrm{Co} / \mathrm{CeO}_{2}$ catalyst has been investigated. The catalytic performance of the $\mathrm{Co} / \mathrm{CeO}_{2}$ catalyst which was prepared by wet impregnation was studied at reaction temperature ranged 923-1023 K and feed ratios between 0.1-1.0. The catalyst show good activity towards $\mathrm{H}_{2}$ and $\mathrm{CO}$ selectivity and yield with highest $\mathrm{H}_{2}$ and $\mathrm{CO}$ selectivity of $19.56 \%$ and $20.95 \%$ respectively, while the highest yield of $41.98 \%$ and $38.05 \%$ were obtained for $\mathrm{H}_{2}$ and $\mathrm{CO}$ respectively. Syngas ratio close to unity was produced, which further confirm the suitability of the methane dry reforming over $\mathrm{Co} / \mathrm{CeO}_{2}$ for the production of syngas for Fischer-Tropsch synthesis. This study has reiterated the potential of $\mathrm{Co} / \mathrm{CeO}_{2}$ which exhibited promising catalytic properties for the production of hydrogen and syngas.

\section{Acknowledgement}

The authors would like to acknowledge the Science fund research fund RDU130501 granted by the Ministry of Science, Technology and Innovation Malaysia (MOSTI) and the DSS scholarship granted to the first author by Universiti Malaysia Pahang.

\section{References}

[1] Ursua, A. (2012). Hydrogen production from water Electrolysis: Current Status and Future Trends: in Proceedings of the IEEE, 100 (2): 410-426.

[2] Kirtay, E. (2011). Recent advances in production of hydrogen from biomass. Energy Convers. Manag., 52 (4): 1778-1789.

[3] Balat, H., Kirtay, E. (2010). Hydrogen from biomass - Present scenario and future prospects. Int. J. Hydrogen Energy, 35 (14): 74167426 .
[4] Balat, M., Balat, M. (2009). Political, economic and environmental impacts of biomassbased hydrogen. Int. J. Hydrogen Energy, 34 (9): 3589-3603.

[5] Mekhilef, S., Saidur, R., Safari, A. (2012). Comparative study of different fuel cell technologies. Renew. Sustain. Energy Rev., 16(1): 981-989.

[6] Kirubakaran, A., Jain, S., Nema, R.K. (2009). A review on fuel cell technologies and power electronic interface. Renew. Sustain. Energy Rev., 13 (9): 2430-2440

[7] Arora, K. (2014). International journal of Emerging Trends in Science and Technology. Int. J. Emerg. Trends Sci. Technol., 1(10): 1691-1698.

[8] Sharaf, O.Z., Orhan, M.F. (2014). An overview of fuel cell technology: Fundamentals and application. Renew. Sustain. Energy Rev., 32: 810-853.

[9] Xiong, H., Moyo, M., Motchelaho, M.A., Tetana, Z.N., Dube, S.M.A., Jewell, L.L., Coville, N.J. (2014). Fischer-Tropsch synthesis: Iron catalysts supported on N-doped carbon spheres prepared by chemical vapor deposition and hydrothermal approaches. $J$. Catal., 311: 80-87.

[10] Gabriel, K.J., Noureldin, M., El-Halwagi, M. M., Linke, P., Jiménez-Gutiérrez, A., Martínez, D.Y. (2014). Gas-to-liquid (GTL) technology: Targets for process design and water-energy nexus. Curr. Opin. Chem. Eng., 5: $49-54$.

[11] Aasberg-Petersen, K., Dybkjær, I., Ovesen, C. V., Schjødt, N.C., Sehested, J., Thomsen, S.G. (2011). Natural gas to synthesis gas - Catalysts and catalytic processes. J. Nat. Gas Sci. Eng., 3 (2): 423-459.

[12] Li, K., Zhang, R., Bi, J. (2010). Experimental study on syngas production by co-gasification of coal and biomass in a fluidized bed. Int. J. Hydrogen Energy, 35(7): 2722-2726.

[13] Wu, T.Y., Mohammad, A.W. (2007). Palm oil mill effluent (POME) treatment and bioresources recovery using ultrafiltration membrane: effect of pressure on membrane fouling Biochem. Eng. J., 35(3): 309-317.

[14] Yoshiie, R., Taya, Y., Ichiyanagi, T., Ueki, Y., Naruse, I. (2013). Emissions of particles and trace elements from coal gasification. Fuel, 108: 67-72.

[15] Man, Y., Yang, S., Xiang, D., Li, X., Qian, Y. (2014). Environmental impact and technoeconomic analysis of the coal gasification process with/without $\mathrm{CO}_{2}$ capture. J. Clean. Prod., 71: 59-66. 
[16] Bhandari, R., Trudewind, C. A., Zapp, P. (2014). Life cycle assessment of hydrogen production via electrolysis: a review. J. Clean. Prod., 85: 151-163.

[17] Koh, A., Chen, L., Keeleong, W., Johnson, B., Khimyak, T., Lin, J. (2007). Hydrogen or synthesis gas production via the partial oxidation of methane over supported nickel-cobalt catalysts. Int. J. Hydrogen Energy, 32(6): 725-730.

[18] Kothari, R., Buddhi, D., Sawhney, R.L. (2008). Comparison of environmental and economic aspects of various hydrogen production methods. Renew. Sustain. Energy Journal, 12(2): 553-563

[19] Sehested, J. (2006). Four challenges for nickel steam-reforming catalysts Catal. Today, 111 (1-2): 103-110.

[20] Braga, T.P., Santos, R.C.R., Sales, B.M.C., da Silva, B.R., Pinheiro, A.N., Leite, E.R., Valentini, A. (2014). $\mathrm{CO}_{2}$ mitigation by carbon nanotube formation during dry reforming of methane analyzed by factorial design combined with response surface methodology," Chinese J. Catal., 35 (4): 514-523.

[21] Whitemore, N.W. (2007). Greenhouse gas catalytic reforming to syngas. Columbia University in the City of New York.

[22] Budiman, A.W., Song, S.H., Chang, T.S., Shin, C.H., Choi, M.J. (2012). Dry Reforming of Methane Over Cobalt Catalysts: A Literature Review of Catalyst Development. Catal. Surv. from Asia, 16(4): 183-197.

[23] Ruckenstein, E., Wang, H.Y. (2002). Carbon Deposition and Catalytic Deactivation during $\mathrm{CO}_{2}$ Reforming of $\mathrm{CH}_{4}$ over $\mathrm{Co} / \gamma-\mathrm{Al}_{2} \mathrm{O}_{3}$ Catalysts, J. Catal., 205(2): 289-293.

[24] Lavoie, J.M. (2014). Review on dry reforming of methane, a potentially more environmentally-friendly approach to the increasing natural gas exploitation, Front. Chem., 2: 1-17.

[25] Luisetto, I., Tuti, S., Di Bartolomeo, E. (2012). $\mathrm{Co}$ and $\mathrm{Ni}$ supported on $\mathrm{CeO}_{2}$ as selective bimetallic catalyst for dry reforming of methane. Int. J. Hydrogen Energy, 37: 1599215999.

[26] Abasaeed, A.E., Al-fatesh, A.S., Naeem, M.A., Ibrahim, A.A., Fakeeha, A.H. (2015) Catalytic performance of $\mathrm{CeO}_{2}$ and $\mathrm{ZrO}_{2}$ supported $\mathrm{Co}$ catalysts for hydrogen production via dry reforming of methane, Int. Hydrog. Energy, 40: 6818-6826.

[27] Lee, S.S., Zhu, H., Contreras, E.Q. Prakash, A., Puppala, H.L., Colvin, V.L. (2012). High temperature decomposition of cerium precursors to form ceria nanocrystal libraries for biological applications, Chem. Mater. 24: 424432 .
[28] Djaidja, A., Libs, S., Kiennemann, A., Barama, A. (2006). Characterization and activity in dry reforming of methane on $\mathrm{NiMg} / \mathrm{Al}$ and $\mathrm{Ni} / \mathrm{MgO}$ catalysts, Catal. Today, 113(3-4): 194-200.

[29] Abd. El-Hafiz, D.R., Ebiad, M.A., Elsalamony, R.A. (2014). Hydrogen selectivity and carbon behavior during gasoline steam reforming over nano- $\mathrm{Al}_{2} \mathrm{O}_{3}$ catalysts. Mater. Renew. Sustain. Energy, 3(3): 1-13.

[30] Foo, S.Y., Cheng, C.K., Nguyen, T.H., Adesina, A.A. (2011). Kinetic study of methane $\mathrm{CO}_{2}$ reforming on $\mathrm{Co}-\mathrm{Ni} / \mathrm{Al}_{2} \mathrm{O}_{3}$ and $\mathrm{Ce}-\mathrm{Co}$ $\mathrm{Ni} / \mathrm{Al}_{2} \mathrm{O}_{3}$ catalysts. Catal. Today, 164(1): 221226.

[31] Du, X., Zhang, D., Shi, L., Gao, R., Zhang, J. (2012). Morphology Dependence of Catalytic Properties of $\mathrm{Ni} / \mathrm{CeO}_{2}$ Nanostructures for Carbon Dioxide Reforming of Methane. $J$. Phys. Chem., 1: 10009-10016.

[32] Da Silva, A.M., De Souza, K.R., Mattos, L.V., Jacobs, G., Davis, B.H., Noronha, F.B. (2011). The effect of support reducibility on the stability of $\mathrm{Co} / \mathrm{CeO}_{2}$ for the oxidative steam reforming of ethanol, Catal. Today, 164: 234239.

[33] Verykios, X.E. (2003). Catalytic dry reforming of natural gas for the production of chemicals and hydrogen. Int. J. Hydrogen Energy, 28(10): 1045-1063.

[34] Shi, C., Zhang, A., Li, X., Zhang, S., Zhu, A., $\mathrm{Ma}, \mathrm{Y} ., \mathrm{Au}, \mathrm{C}$. (2012). Ni-modified $\mathrm{Mo}_{2} \mathrm{C}$ catalysts for methane dry reforming, Appl. Catal. A Gen., 432: 164-170.

[35] Sajjadi, S. M., Haghighi, M., Rahmani, F. (2014). Dry reforming of greenhouse gases $\mathrm{CH}_{4} / \mathrm{CO}_{2}$ over $\mathrm{MgO}$-promoted $\mathrm{Ni}-\mathrm{Co} / \mathrm{Al}_{2} \mathrm{O}_{3}$ $\mathrm{ZrO}_{2}$ nanocatalyst: effect of $\mathrm{MgO}$ addition via sol-gel method on catalytic properties and hydrogen yield. J. Sol-Gel Sci. Technol. 70: 111114

[36] Rahemi, N., Haghighi, M., Babaluo, A.A., Allahyari, S., Jafari, M.F. (....) Syngas production from reforming of greenhouse gases $\mathrm{CH}_{4} / \mathrm{CO}_{2}$ over $\mathrm{Ni}-\mathrm{Cu} / \mathrm{Al}_{2} \mathrm{O}_{3}$ nanocatalyst: Impregnated vs. plasma-treated catalyst, Energy Convers. Manag., 84: 50-59.

[37] Serrano-Lotina, A., Daza, L. (2014). Influence of the operating parameters over dry reforming of methane to syngas. Int. J. Hydrogen Energy, 39(8): 4089-4094.

[38] Sharifi, M., Haghighi, M., Rahmani, F., Karimipour, S. (2014). Syngas production via dry reforming of $\mathrm{CH}_{4}$ over Co- and $\mathrm{Cu}$ promoted $\mathrm{Ni} / \mathrm{Al}_{2} \mathrm{O}_{3}-\mathrm{ZrO}_{2}$ nanocatalysts synthesized via sequential impregnation and solgel methods. J. Nat. Gas Sci. Eng., 21: 9931004. 
[39] Nematollahi, B., Rezaei, M., Khajenoori, M. (2011). Combined dry reforming and partial oxidation of methane to synthesis gas on noble metal catalysts. Int. J. Hydrogen Energy, 36 (4): 2969-2978.

Selected and Revised Papers from The International Conference on Fluids and Chemical Engineering (FluidsChE 2015) (http://fluidsche.ump.edu.my/index.php/en/) (Malaysia, 25-27 November 2015) after Peer-reviewed by Scientific Committee of FluidsChE 2015 and Reviewers of BCREC 